\author{
Bronisław Górz \\ Zakład Geografii Ekonomicznej \\ Tomasz Rachwal \\ Zakład Przedsiębiorczości i Gospodarki Przestrzennej \\ Instytut Geografii \\ Akademia Pedagogiczna w Krakowie
}

\title{
Uwagi do projektu zmiany podstawy programowej podstaw przedsiębiorczości (zrealizowanej przez Instytut Spraw Publicznych na zlecenie Ministerstwa Edukacji Narodowej)
}

Procesy transformacji systemu gospodarowania dokonujące się w Polsce, w warunkach nasilających się procesów globalizacji gospodarki światowej i integracji gospodarki europejskiej, wymagają coraz precyzyjniejszego poznania złożonych reguł funkcjonowania i rozwoju poszczególnych podmiotów gospodarki narodowej, w tym przedsiębiorstw i instytucji, a także całej gospodarki. Konieczne są więc działania na rzecz edukacji społeczeństwa w tym zakresie, aby nie tylko poznać złożoność tych reguł, ale także wiedzieć, jak w ich ramach działać i rozwijać się. Odnosi się to zwłaszcza do młodzieży szkolnej, która w dorosłym życiu znajdzie się w zupełnie nowych warunkach kształtowania się procesów gospodarczych w różnej skali przestrzennej: od gospodarki lokalnej po gospodarkę krajową i gospodarkę światową.

Dlatego z dużym uznaniem należy ocenić działania instytucji edukacyjnych dążących do systematycznej modernizacji treści kształcenia w zakresie przedsiębiorczości, czego wyrazem jest kolejna propozycja podstawy programowej kształcenia ogólnego, przygotowana przez Instytut Spraw Publicznych na zlecenie Ministerstwa Edukacji Narodowej. Pomijając kwestie ogólnych założeń przebudowy podstawy programowej, m.in. jak się wydaje błędne zakwalifikowanie geografii do zespołu roboczego „Przyrodoznawstwo” i tym samym opracowanie podstawy programowej podstaw przedsiębiorczości przez inny zespół roboczy (nauk społecznych) ${ }^{1}$, należy podkreślić, że od aktualnie obowiązującej jest ona znacznie lepsza. Zgodnie z ogólnymi założeniami przebudowa podstawy programowej ma charakter ewolucyjny, a nie „,rewolucyjny”, dzięki czemu różnice między podstawą programową proponowaną a obecnie funkcjonującą są niewielkie.

W wyniku analizy III wersji projektu nowej podstawy programowej podstaw przedsiębiorczości nasuwają się pewne sugestie dotyczące założeń ogólnych, przebudowy założeń i celów kształcenia oraz układu treści i wymagań. Analizę przeprowadził zespół Zakładu Przedsiębiorczości i Gospodarki Przestrzennej Instytutu Geografii Akademii Pedagogicznej w Krakowie, w składzie: prof. dr hab. Zbigniew Zioło wraz ze współpracownikami, prof. dr Bronisław Górz, prof. dr hab. Zbigniew Makieła, prof. dr hab. Roman Fedan, dr Tomasz Rachwał, mgr Monika Borowiec, mgr Wioletta Kilar.

\footnotetext{
${ }^{1} \mathrm{O}$ niektórych błędnych założeniach przebudowy podstawy programowej szerzej pisała M. Tracz w Uwagach o założeniach wstęnych nowej podstawy programowej (publikacja dostępna na stronie internetowej Instytutu Spraw Publicznych: www.isp.org.pl)
} 
Odnośnie do założeń ogólnych podstawy programowej podstaw przedsiębiorczości należy zwrócić uwagę na bardzo duże podobieństwo między propozycją podstawy programowej dla szkoły średniej kończącej się maturą a propozycją dla szkoły zawodowej. Lektura obu propozycji wskazuje, że podstawa programowa dla zasadniczej szkoły zawodowej jest nieco okrojoną wersją podstawy programowej dla szkół maturalnych. Nasuwa się więc pytanie, czy w przypadku przedmiotu podstawy przedsiębiorczości nie należałoby zrezygnować z tego podziału i stworzyć jedną podstawę programową dla szkół ponadgimnazjalnych. Przedmiot ten ma przygotowywać uczniów do życia we współczesnym świecie, a zatem niecelowe wydaje się założenie, że uczniowie szkół zawodowych powinni być w mniejszym stopniu wyposażeni w tę umiejętność. Wręcz przeciwnie; ze względu na to, że wielu absolwentów szkół zawodowych (w przeciwieństwie do absolwentów szkół kończących się maturą) bezpośrednio po ukończeniu szkoły wchodzi w okres życia zawodowego (szukając zatrudnienia bądź zakładając własną firmę), w przypadku szkoły zawodowej powinno się dążyć do rozszerzania zakresu treści programowej. Oczywiście przy założeniu przynajmniej jednakowego podejścia do wymagań programowych, przedmioty te w obydwu typach szkół powinny być traktowane jednakowo pod względem liczby godzin. Konieczne byłyby więc odpowiednie zmiany w ramowym planie nauczania. Proponujemy zatem stworzenie jednej podstawy programowej dla szkół ponadgimnazjalnych wszystkich typów, co oczywiście nie wyklucza położenia przez nauczyciela nacisku na niektóre treści programowe, a zmniejszenia roli innych treści, jeśli są one realizowane w szerszym stopniu na innych przedmiotach, np. w szkołach o profilu ekonomicznym. Jako nietrafną należy też ocenić decyzję autorów III wersji projektu (w stosunku do poprzednich wersji) o włączeniu w zasadniczej szkole zawodowej treści z zakresu przedsiębiorczości do przedmiotu wiedza o społeczeństwie, co będzie prowadzić do ich marginalizacji. Szczególnie, jeśli w wyniku zmian przedmiot będzie w całości realizowany przez nauczyciela WOS, który nie odbył studiów podyplomowych w zakresie nauczania przedsiębiorczości.

Należy się również zastanowić nad tym, czy propozycja podstawy programowej nie powinna zawierać wersji rozszerzonej, jak w wypadku innych przedmiotów. Przemawiają za tym dwa istotne argumenty. Po pierwsze, chociaż podstawy przedsiębiorczości nie są przedmiotem egzaminacyjnym na maturze, należy się spodziewać, że w niedługim czasie prawdopodobnie nim zostana, co będzie wymagało umożliwienia uczniom zdawania go w wersji rozszerzonej. Autorzy projektu powinni więc w tej sprawie skonsultować się z ministerstwem edukacji narodowej, żeby nie okazało się, że podstawa po zatwierdzeniu już „,na starcie” będzie wymagała nowelizacji, z powodu wprowadzenia matury z podstaw przedsiębiorczości. Po drugie, w wielu szkołach jest potrzeba realizacji tego przedmiotu na poziomie rozszerzonym na skutek m.in. wprowadzenia egzaminów wstępnych z przedsiębiorczości w niektórych uczelniach ekonomicznych w Polsce. Należy się spodziewać, że uczelnie te nie zrezygnują z przeprowadzania egzaminów do czasu wprowadzenia matury z podstaw przedsiębiorczości.

Odnosząc się do szczegółowych zapisów w propozycji podstawy programowej, wychodzimy z założenia, że edukację przedsiębiorczości należy rozpocząć od poznania kształtowania się procesów gospodarczych i do nich dostosować pozostałe treści edukacyjne dla ucznia, który w najbliższej przyszłości będzie wkraczał w okres pracy zawodowej i poszukiwał swojego miejsca w życiu. Proponujemy taką przebudowę założeń, celów kształcenia i układu treści, by wychodziły one od zagadnień makroekonomicznych, następnie obejmowały zagadnienia mikroekonomiczne, co dałoby podstawę do kształtowania postaw i umiejętności zachowania się na rynku pracy. 


\section{Uwagi do „Założeń"}

Analizując zapisy założeń, warto zwrócić uwagę, że jest to bardzo ważny element podstawy programowej, nakreśla bowiem charakter nowego przedmiotu i jego zasadnicze przesłanie. Dlatego ze szczególną starannością należy wyeliminować z założeń skróty myślowe oraz niejasne i niezręczne sformułowania ${ }^{2}, \mathrm{np}$. w akapicie drugim niepotrzebne i nieszczęśliwie sformułowane wydaje się zdanie pierwsze: ,,przedmiot ma charakter praktyczny”. Chociaż, jak się można domyślać, wynika to zapewne $\mathrm{z}$ chęci podkreślenia, że przedmiot powinien przede wszystkim wyposażać uczniów w umiejętności, a nie w wiedzę teoretyczna, niedopuszczalne jest robienie z niego przedmiotu czysto praktycznego, jak robótki ręczne. Zrozumienie mechanizmów gospodarczych i kształtowanie umiejętności wymaga przecież wyposażenia uczniów w wiedzę o charakterze teoretycznym. Będzie to tym bardziej istotne, jeśli podstawy przedsiębiorczości zostaną przedmiotem maturalnym. W kolejnym zdaniu nieszczęśliwe wydaje się sformułowanie „realne życie gospodarcze" (czy istnieje nierealne?). Ponadto należy zauważyć, że z III wersji projektu chyba zbyt pochopnie wykreślono niektóre trafne sformułowania (pochodzące z wcześniejszych wersji) w pierwszym akapicie wstępu. Wydaje się też, że w założeniach pominięto ważną kwestię, jaką jest postępowanie etyczne, co zostało mocno podkreślone w dalszej części projektu podstawy. Wydaje się, że etyczne spojrzenie na przedsiębiorczość powinno już być zasygnalizowane w założeniach. Dlatego proponujemy, aby założenia miały następujące brzmienie:

Nauczanie podstaw przedsiębiorczości zmierza do wychowania człowieka twórczego, aktywnego, doceniającego swoją wartość, umiejącego wytyczać sobie cele, zdolnego do racjonalnego i wytrwałego działania zgodnie z zasadami etycznymi. Służy temu m.in. zapoznanie ucznia z procesami zachodzącymi w gospodarce oraz celami i zasadami efektywnego gospodarowania, a także wykształcanie umiejętności analizy procesów ekonomicznych, aktywnego zachowania się na rynku pracy i podejmowania własnej działalności gospodarczej. W procesie dydaktycznym należy stosować głównie aktywizujące metody nauczania $\mathrm{z}$ wykorzystaniem podstawowych informacji o procesach gospodarczych, społecznych i kulturowych.

\section{Uwagi do „Celów kształcenia”}

Nieco wątpliwości budzą poszczególne sformułowania celów kształcenia, np.:

1. w punkcie pierwszym sformułowanie, ,umiejętność racjonalnego gospodarowania własnymi pieniędzmi oraz budżetem gospodarstwa domowego" można by skrócić, gdyż własne pieniądze są elementem budżetu gospodarstwa domowego;

2. w punkcie drugim niezręcznie sformułowano pierwszą część zdania: „potrzeba samozatrudnienia” (raczej „gotowość do samozatrudnienia”); ponadto wydaje się, że uczeń powinien wiedzieć, jak prowadzić działalność gospodarczą, a nie tylko jak ją zaplanować i uruchomić. Przy takich założeniach programowych uczniowie zostaliby przedsiębiorcami, którzy potrafią tylko napisać plan biznesowy i zarejestrować firmę, a przecież najtrudniejsze jest jej prowadzenie.

Ponadto wydaje się, że cele powinny zostać usystematyzowane, dlatego przy założeniu, że powinno się wyjść od spojrzenia makroekonomicznego, punkt 5 powinien występować jako pierwszy. Dlatego proponujemy następujące sformułowanie celów kształcenia:

1. Poznanie rynkowego mechanizmu funkcjonowania gospodarki oraz procesów funkcjonowania gospodarki polskiej w warunkach nasilających się procesów integracji europejskiej i globalizacji.

\footnotetext{
${ }^{2}$ Lista szczegółowych uwag byłaby dłuższa, ale wiele niejasności w III wersji projektu wyeliminowano.
} 
2. Poznanie reguł gospodarowania finansami publicznymi oraz umiejętność racjonalnego gospodarowania budżetem gospodarstwa domowego.

3. Umiejętność aktywnego zachowania się na rynku pracy.

4. Umiejętności planowania, uruchamiania i prowadzenia własnej działalności gospodarczej.

5. Umiejętność efektywnego komunikowania się i działania w zespole.

6. Kształtowanie postaw etycznych w życiu gospodarczym i poznanie metod przeciwdziałania zjawiskom patologicznym.

\section{Uwagi do „Treści kształcenia”}

W nawiązaniu do przedstawionych propozycji założeń i usystematyzowanych celów kształcenia proponujemy zmienić układ treści kształcenia według następującego porządku:

1. Rynek - cechy, funkcje, instytucje:

a) elastyczność popytu i podaży (obliczanie wskaźników i ich praktyczne znaczenie, wpływ poziomu dochodów na strukturę wydatków konsumentów);

b) giełda papierów wartościowych jako przykład instytucji rynkowej;

c) inwestowanie kapitału (formy, kryteria i ryzyko).

2. Rola państwa w gospodarce:

a) funkcje gospodarcze państwa, główne mierniki rozwoju gospodarczego;

b) funkcje budżetu państwa i budżetów jednostek samorządu terytorialnego;

c) podatki.

3. Gospodarka światowa, europejska i krajowa:

a) współpraca gospodarcza Polski z zagranicą;

b) gospodarka Polski w Unii Europejskiej;

d) globalizacja gospodarki.

4. Funkcje banków w gospodarce:

a) typy banków;

b) polityka pieniężna banku centralnego;

b) rodzaje usług bankowych.

5. Funkcjonowanie przedsiębiorstw:

a) najważniejsze formy organizacyjno-prawne przedsiębiorstw;

b) majątek przedsiębiorstwa, źródła finansowania i ocena kondycji finansowej przedsiębiorstwa;

c) zarządzanie przedsiębiorstwem, metody analizy miejsca przedsiębiorstwa na rynku, rola marketingu w działalności przedsiębiorstwa.

6. Gospodarstwo domowe:

a) gospodarowanie budżetem domowym;

b) ochrona praw konsumentów;

c) ubezpieczenia osobowe (ze szczególnym uwzględnieniem ubezpieczeń społecznych i zdrowotnych) i majątkowe.

7. Postawa przedsiębiorcza i aktywność zawodowa człowieka:

a) cechy i przejawy postawy przedsiębiorczej;

b) mocne i słabe strony własnej osobowości;

c) motywy aktywności zawodowej, wyznaczanie celów oraz sposobów ich osiagania, ,inwestowanie w siebie",

d) planowanie własnej kariery zawodowej.

8. Funkcjonowanie rynku pracy:

a) czynniki popytu i podaży pracy;

b) bezrobocie. 
9. Poszukiwanie pracy:

a) metody, źródła informacji o miejscach pracy;

b) dokumenty potrzebne w ubieganiu się o pracę: list motywacyjny i życiorys zawodowy $(\mathrm{CV})$;

c) rozmowa kwalifikacyjna.

10. Prawo pracy:

a) nawiązywanie i rozwiązywanie stosunku pracy;

b) podstawowe prawa i obowiązki pracownika oraz pracodawcy.

11. Samozatrudnienie:

a) pomysł na działalność gospodarczą, uproszczony plan biznesowy;

b) procedury rejestracji działalności gospodarczej.

12. Praca zespołowa:

a) cele i zasady;

b) formy komunikacji werbalnej i niewerbalnej;

c) czynniki skutecznego porozumiewania się i źródła barier komunikacyjnych;

d) cechy i rola lidera zespołu, proces podejmowania decyzji oraz kierowanie ludźmi;

e) prowadzenie negocjacji i metody rozwiązywanie konfliktów.

13. Etyka w pracy i biznesie:

a) wartość postawy etycznej;

b) przeciwdziałanie mobbingowi, korupcji, nieuczciwej konkurencji i praktykom monopolistycznym.

\section{Omówienie proponowanych zmian w treściach kształcenia}

W stosunku do projektu wydaje się celowe połączenie punktu nr [1] ${ }^{3}$ i [9] (w nowy punkt 7), ponieważ zawierają wzajemnie uzupełniające się treści.

Punkt 3 [8] ma brzmienie zbyt szerokie („Polska, Europa i świat”), co sugeruje, że chodzi o zmieszczenie całej problematyki dotyczącej Polski, Europy i świata w tej części kształcenia, dlatego proponujemy następujące brzmienie tego punktu: „Gospodarka światowa, europejska i krajowa”. Wydaje się, że konieczne jest unikanie w podstawie programowej haseł ogólnikowych, które mogą pasować także do wielu innych przedmiotów (np. geografii czy historii). Podpunkty „a” i ,b” można by połączyć w jeden „współpraca gospodarcza Polski z zagranicą” (bez szczegółowego odwoływania się do kursu walutowego itd.) Podpunkt „,b” [,c”] należy doprecyzować „Gospodarka Polski w Unii Europejskiej”. Jest to bardzo ważne, gdyż nie można dopuścić do tego, by odczytywano, że treści z zakresu integracji Polski z UE są realizowane w całości na przedmiocie podstawy przedsiębiorczości (a tak wynikałoby z proponowanego zapisu). W przeciwnym wypadku te same treści byłyby realizowane na podstawach przedsiębiorczości, geografii, wiedzy o społeczeństwie, a nawet historii (w zakresie historii integracji europejskiej). Ponieważ problematyka integracji europejskiej jest ważna z punktu widzenia celów kształcenia w Polsce, która jest członkiem UE, wydaje się, że treści z zakresu integracji europejskiej powinny być podzielone pomiędzy 4 przedmioty w następujący sposób:

a) na historii powinna być realizowana historia integracji europejskiej;

b) na lekcjach wiedzy o społeczeństwie - problematyka funkcjonowania UE jako organizacji (m.in. instytucje, sprawy obywatelskie);

\footnotetext{
${ }^{3}$ Dla jasności punkty treści programowych $\mathrm{z}$ analizowanego projektu ISP ujęto w nawiasy kwadratowe; bez nawiasów pisane są punkty treści kształcenia po modyfikacji (tj. po zmianach proponowanych w tym opracowaniu).
} 
c) na lekcjach geografii - problematyka zróżnicowania społeczno-gospodarczego państw UE, powiązań przestrzennych i współpracy między krajami UE oraz powiązań między UE a innymi państwami;

d) na lekcjach podstaw przedsiębiorczości - treści z zakresu funkcjonowania gospodarki unijnej, ze szczególnym uwzględnieniem budżetu UE i funduszy unijnych podnoszących konkurencyjność gospodarki na poziomie regionalnym i lokalnym oraz społeczeństwa; jeśli na lekcjach podstaw przedsiębiorczości mają być poruszane aspekty gospodarcze integracji, to problematyka funduszy unijnych powinna być przeniesiona z podstawy wiedzy o społeczeństwie do przedmiotu podstawy przedsiębiorczości.

Punktowi 4 [7] lepiej byłoby nadać brzmienie „Funkcje banków w gospodarce” (szczególnie, że wyliczenie po dwukropku sugeruje, iż inflacja jest typem banku) i wyróżnić tu 3 podpunkty (ze względu na fakt, że jest to złożone i ważne zagadnienie): a) Typy banków; b) Polityka pieniężna banku centralnego (tu także zawarta będzie problematyka inflacji); c) Rodzaje usług bankowych.

Punkt 5 [5] powinien raczej brzmieć „Funkcjonowanie przedsiębiorstwa”. W podpunkcie „a” zamiast określenia ,jednostek gospodarczych” powinno się używać konsekwentnie ,przedsiębiorstw”. Podpunkt „b” niepotrzebnie zawiera wyliczankę elementów oceny kondycji finansowej, można go wiec skrócić do „Majątek przedsiębiorstwa, źródła finansowania i ocena kondycji finansowej”. Ponadto w punkcie 5 wyraźnie brakuje podpunktu dotyczącego „metod zarządzania przedsiębiorstwem” oraz analizy ,,miejsca przedsiębiorstwa na rynku i roli marketingu” (należałoby dołożyć jako podpunkt „c”). Należy się także zastanowić, czy nie powinna się tu znaleźć problematyka ubezpieczeń gospodarczych przedsiębiorstw, gdyż w p. 6 [3] - jak się wydaje - obejmuje ona tylko ubezpieczenia gospodarstw domowych. W efekcie proponowanych zmian w podstawie znalazłaby się problematyka ubezpieczeń przedsiębiorstw, co z punktu widzenia osób zakładających własną firmę jest bardzo ważne. Innym wyjściem byłoby stworzenie osobnego punktu dotyczącego ubezpieczeń (w miejsce zlikwidowanego jednego punktu). Są to ważne kwestie, dlatego warto się zastanowić, czy nie należy ich wyeksponować jako oddzielnego punktu treści programowej, który mógłby być połączony z inną ważną treścią kształcenia - dotyczącą podatków - w jeden punkt „Podatki i ubezpieczenia”.

W punkcie 6 [3] przy gospodarstwie domowym należałoby wykreślić niezbyt trafne sformułowanie „miejsce i organizator konsumpcji”. Trudno sobie wyobrazić gospodarstwo domowe jako organizatora czegokolwiek (organizatorem mogą być ludzie, członkowie danego gospodarstwa domowego).Ponadto należałoby się zastanowić, czy w powszechnym rozumieniu gospodarstwo domowe to jest jedyne miejsce, w którym dokonuje się konsumpcji (por.: usługa restauracyjna, pobyt na wczasach itp.). Ponadto w podpunkcie ,a” należałoby wykreślić słowo „racjonalne” (samo gospodarowanie wystarczy), gdyż oznaczałoby to zgodę na stwierdzenie, że jakiekolwiek nieracjonalne działanie można nazwać gospodarowaniem. W punkcie ,c” zamiast określenia „[ubezpieczenia] gospodarcze”, może lepiej byłoby użyć „,[ubezpieczenia] majątkowe i osobowe", w przeciwnym razie mogą się zrodzić watpliwości, czy pojęcie to obejmuje takie ubezpieczenia, jak polisy na życie, ubezpieczenie OC w życiu prywatnym i inne prywatne produkty ubezpieczeniowe (najczęściej nieobowiązkowe). Należy bowiem podkreślić, że w praktyce ubezpieczeniowej pojęcie „ubezpieczenia gospodarcze” z reguły obejmuje ubezpieczenia osób prawnych i fizycznych prowadzących działalność gospodarczą. Ponieważ ubezpieczenia społeczne i zdrowotne zalicza się także do ubezpieczeń osobowych, punkt ten musi zostać odpowiednio przeredagowany, aby pozostało podkreślone znaczenie ubezpieczeń społecznych i zdrowotnych w systemie ubezpieczeniowym. 
Punktowi 8 [10] można by nadać brzmienie „Funkcjonowanie rynku pracy”. Wydaje się też, że podpunkt „c” (,,planowanie własnej kariery zawodowej”) powinien zostać przeniesiony do punktu 7 ,Postawa przedsiębiorcza i aktywność zawodowa człowieka” (jako podpunkt „d”), gdyż odnosi się nie do rynku pracy (w sensie makroekonomicznym), lecz do aktywności zawodowej człowieka.

W punkcie 12 [2] wydaje się niezbędne dodanie zapisu dotyczącego problematyki roli lidera zespołu oraz dodanie punktu ,e” - ,prowadzenie negocjacji i metody rozwiązywania konfliktów", bo bez tych umiejętności trudno wyobrazić sobie skuteczną komunikację międzyludzką w pracy i w działalności gospodarczej.

Należy się zastanowić, czy w punkcie 13 [14] dla przejrzystości nie powinno się wyróżnić treści po myślniku w postaci podpunktów (analogicznie do innych punktów). Ponadto słowo „mobbing” należałoby przesunąć przed korupcję, skoro punkt ma brzmienie: „Etyka w pracy [na pierwszym miejscu] i biznesie [na drugim]".

\section{Uwagi do „Wymagań”}

Kolejną część podstawy programowej stanowią wymagania programowe. Do koncepcji ich sformułowania należy się odnieść pozytywnie. W dotychczasowej podstawie programowej istnieją tzw. osiagnięcia, które w dużej mierze są powtórzeniem treści kształcenia. Intencje autorów, zmierzające do rezygnacji z zapisów tzw. osiagnięć na rzecz jasnego sformułowania wymagań programowych, są więc dobre. Szczegółowa analiza zapisów „wymagań” prowadzi jednak do wniosku, że część z nich powinna zostać zmieniona lub wykreślona.

W punkcie $2.2^{4}$ niejasny wydaje się zapis ,[znać cechy] dobrego kierownika zespołu”. Należałoby wykreślić przymiotnik ,dobry”, w przeciwnym razie pozostają watpliwości, co to znaczy „dobry” kierownik (należałoby wtedy to uściślić, na co nie ma miejsca w podstawie programowej). Konieczne wydaje się dopisanie punktu 2.7 „Negocjować i rozwiązywać konflikty"- jako najważniejsze przejawy umiejętności interpersonalnych. W przypadku przeładowania wymaganiami można by zrezygnować z o wiele mniej istotnego punktu 2.4.

W punkcie 3.1 należałoby wykreślić słowo „ocenić” (jako zbędne), punkt 3.3 zmienić na „znać cele i cechy ubezpieczeń osobowych (ze szczególnym uwzględnieniem ubezpieczeń społecznych i zdrowotnych) i majątkowych" (analogicznie do uzasadnionych wyżej zmian w treściach kształcenia).

Wydaje się, szczególnie w obliczu uzasadnionej konieczności dopisania kilku wymagań, że można zrezygnować z punktów 4.4 i 4.5, a punkty 4.6 i 4.8 (jako bardzo do siebie podobne i w wymowie tożsame) połączyć w punkt ,znać kryteria i opisać sposoby inwestowania pieniędzy”. W punkcie 4.7 należy wykreślić wyliczenie wskaźników giełdowych (jest zbyt szczegółowe, co zresztą - jak się wydaje - stoi w sprzeczności z założeniami przebudowy podstawy). Punkt ten mógłby brzmieć: „Rozróżniać akcje i obligacje, rozumieć funkcjonowanie giełdy papierów wartościowych”. Pozostaje jednak wattpliwość co do sformułowania,,rozróżniać” (może wymienić cechy?) i czy tylko, ,akcje i obligacje”, a nie np. także instrumenty pochodne, którymi obrót na giełdzie staje się coraz bardziej popularny.

W punkcie 5.1 wydaje się celowe dopisanie pozostałych 2 spółek prawa handlowego, tzn. komandytowej i komandytowo-akcyjnej. Dzięki temu uczeń będzie rozróżniał wszystkie spółki przewidziane w polskim prawie. Niecelowe wydaje się okrawanie katalogu spółek akurat o te

\footnotetext{
${ }^{4}$ Numeracja zgodnie $\mathrm{z}$ układem $\mathrm{w}$ analizowanej propozycji, przy czym pierwsza cyfra oznacza numer treści, a druga - numer wymagań w obrębie danej treści.
} 
dwie, tym bardziej, że założenie spółki komandytowej przez absolwentów może być w wielu przypadkach uzasadnione. Należy też się zastanowić, czy problematyki tej nie należy poszerzyć o spółkę europejska, której założenie od niedawna jest możliwe także w Polsce. Punkt 5.3 mógłby mieć prostsze brzmienie „Klasyfikować koszty według układu rodzajowego”. Punkt 5.5, jako bardzo czasochłonny w realizacji i trudny do osiagnięcia w założonej liczbie godzin, proponujemy wykreślić. Punkt taki mógłby się znaleźć w wersji rozszerzonej podstawy, chociaż w tym wypadku i tak należałoby się zastanowić, czy akurat te wskaźniki powinny być przedmiotem wymagań, szczególnie że mowa jest nie tylko o interpretowaniu, ale także o obliczaniu wskaźników. Wydaje się, że ze względu na potrzeby edukacji szkolnej w kształceniu ogólnym należy położyć mniejszy nacisk na treści z zakresu tzw. pełnej rachunkowości, a skupić się na uproszczonych formach prowadzania księgowości przez osoby fizyczne prowadzące działalność gospodarczą. Należy bowiem założyć, że uczniowie w pierwszej kolejności zechcą zakładać małe rodzinne firmy, które będą płatnikami podatku dochodowego od osób fizycznych, a nie podatku CIT. Tak więc dobór wskaźników oceny finansowej przedsiębiorstw powinien nawiązywać do uproszczonych form księgowości. Zamiast tego punktu proponujemy dopisać „rozumieć rolę marketingu w działalności przedsiębiorstwa” (w nawiązaniu do uzasadnionych zmian w treściach kształcenia).

W punkcie 6.1 zamiast ,[wyjaśnić] przyczyny aktywności państwa w gospodarce” lepszym sformułowaniem byłoby ,[wyjaśnić] rolę państwa”. W punkcie 6.2 zamiast określenia „,mierniki gospodarki w skali państwa” należałoby użyć sformułowania „mierniki rozwoju gospodarczego". Bezwzględnie powinno się wykreślić koniec zdania w tym punkcie, tj. sformułowanie „Szeregów czasowych, danych przekrojowych”, gdyż wprowadza ono chaos terminologiczny. To właśnie dane (m.in. przekrojowe) mogą być przedstawione w postaci tabel i wykresów, a w takim zapisie (oddzielenie przecinkami) wygląda jakby „szeregi czasowe” czy „dane przekrojowe" były jedną z form graficznych przedstawianych zjawisk. Proponujemy więc zapisać drugą część zdania w następujący sposób: „....) przedstawione w formie tabel i innymi metodami graficznymi prezentacji zjawisk”. Określenie ,inne metody graficzne” jest lepsze, ponieważ dane te mogą być przedstawiane także przestrzennie, w postaci map statycznych - kartogramów i kartodiagramów, których umiejętność interpretacji jest bardzo ważna (właśnie w ten sposób - a nie na wykresie - coraz częściej przedstawia się dane statystyczne dla różnej skali układów przestrzennych, np. państw, województw). W punkcie 6.3 pojawia się po raz kolejny wątpliwość, co to znaczy „,rozróżniać” - czy uczeń ma tylko dostrzegać różnice pomiędzy tymi pojęciami, czy może powinien zdefiniować i wymienić cechy obydwu. Wydaje się, że autorzy projektu podstawy powinni jednoznacznie (w przypisie? we wstępie?) wyjaśnić, co pod terminem „rozróżniać” rozumieją, gdyż w powszechnym użyciu oznacza on ,potrafić dostrzec, stwierdzić różnice między czymś a czymś, odróżniać" ", a wydaje się, że przynajmniej w niektórych przypadkach uczeń powinien nie tylko widzieć różnice, ale także scharakteryzować, wymienić cechy obydwu pojęć (co jest wymaganiem szerszym od „rozróżniać”).

Ze względu na konieczność ograniczenia wymagań (w kontekście dopisania nowych) w punkcie 7.1 należy wykreślić sformułowanie „bazę monetarną i podaż pieniądza” i zrezygnować ze słowa „miary [inflacji]”, a pozostawić jedynie przyczyny i skutki inflacji. Należy się również zastanowić, czy uczniowi jest potrzebna umiejętność obliczania procentu od lokaty/kredytu, skoro większość banków i gospodarczych portali internetowych udostępnia tzw. kalkulatory odsetkowe, które takie odsetki obliczają. Można by zatem zrezygnować z punktu 7.3.

\footnotetext{
${ }^{5}$ Por.: Stownik Współczesnego Języka Polskiego pod red. B. Dunaja, Wilga, Warszawa 1996.
} 
W nawiązaniu do przedstawionej wyżej koncepcji rozdzielenia treści z zakresu edukacji europejskiej na 4 przedmioty, w punkcie 8.1 należałoby dopisać ,[korzyści i koszty] gospodarcze [integracji]". Na marginesie warto zwrócić uwagę, że podobny punkt (chyba niepotrzebnie) znajduje się w projekcie podstawy programowej wiedzy o społeczeństwie. Należy także wykreślić punkt 8.3, a w jego miejsce wpisać ,Znać podstawowe zasady korzystania z funduszy unijnych, ze szczególnym uwzględnieniem funduszy adresowanych do przedsiębiorców i jednostek samorządu terytorialnego w Polsce". Przy okazji należy zwrócić uwagę, że realizacja tej treści kształcenia na lekcjach wiedzy o społeczeństwie powinna koncentrować się na funduszach kierowanych do obywateli niebędących przedsiębiorcami i organizacji społecznych.

W punkcie 10.1 ,sposoby walki” zamienić na „formy przeciwdziałania” bezrobociu (określenie zbyt potoczne).

Punkt 11.4 określenie ,unijny [rynek pracy]” (określenie zbyt wąskie) należy zastąpić zwrotem ,europejski i światowy [rynek pracy]”. Ponadto należy się zastanowić, czy tego punktu nie należałoby przenieść do pozycji ,rynek pracy”.

W punkcie 12.2 należy dopisać umowę na zastępstwo. Należałoby także dopisać punkt 12.3 „znać sposoby rozwiązania umowy o pracę i drogę dochodzenia swoich praw w przypadku naruszania praw pracowniczych".

Punkty 13.1 i 13.2 budzą wątpliwości ze względu na to, że wymaga się w nich od ucznia tylko opracowania planu biznesowego i zarejestrowania firmy. Samo zarejestrowanie firmy wydaje się najmniej istotne (można je zlecić prawnikowi), tym bardziej, że wkrótce te procedury zostaną uproszczone. Wydaje się więc konieczne dopisanie punktu ,znać podstawowe zasady prowadzenia działalności gospodarczej na przykładzie małej firmy". Taki zapis może wydawać się kontrowersyjny ze względu na pojemność znaczeniowa, za jego wprowadzeniem przemawiają jednak dwa argumenty. Po pierwsze - to wymaganie nawiązuje do wcześniejszych treści kształcenia dotyczących przedsiębiorstwa i nawiązywania stosunku pracy - nie wynika więc tylko i wyłącznie z treści kształcenia zawartych w punkcie „Samozatrudnienie”. Po drugie, kształcenie w zakresie przygotowania do prowadzenia własnej firmy nie może ograniczać się do napisania planu biznesowego, znajomości procedury rejestracji i umiejętności analizy wskaźników obrazujących kondycję finansową przedsiębiorstwa. Takim podejściem można wyrządzić wielka krzywdę młodemu człowiekowi, który wyniesie ze szkoły przekonanie, że tylko te elementy są potrzebne do osiąnnięcia sukcesu w biznesie, a przynajmniej wystarczają do prowadzenia własnej firmy. Byłoby to zbyt pochopne i nieodpowiedzialne pchanie uczniów ku samozatrudnieniu, które może się skończyć wielkim rozczarowaniem (a nawet bankructwem firmy). A przecież o powodzeniu w biznesie decyduje umiejętność jego prowadzenia. Jeśli założymy, że przedmiot ten ma przygotować uczniów do prowadzenia własnej małej firmy, niezbędne wydaje się rozszerzenie treści kształcenia i - tym samym - wymagań o zarządzanie przedsiębiorstwem, ze szczególnym uwzględnieniem zarządzania zasobami ludzkim, oraz o szeroko rozumiany marketing. Ponieważ realizacja tak postawionego celu w dotychczasowych ramach czasowych (1 lub 2 godziny w cyklu kształcenia) jest bardzo trudna, wydaje się, że konieczne jest zwiększenie liczby godzin podstaw przedsiębiorczości do co najmniej 3 (w cyklu kształcenia) ${ }^{6}$. Można oczywiście przyjąć założenie, że - ze względu na brak czasu - rezygnuje się z przygotowania uczniów do prowadzenia własnej firmy. W takim jednak wypadku

\footnotetext{
${ }^{6}$ Co prawda zmiana ramowego planu nauczania nie była przedmiotem prac zespołu ds. podstawy programowej, ale - w nawiązaniu do Strategii Rozwoju Edukacji 2007-2013, ogłoszonej przez MENiS - podstawę powinno się tworzyć razem z ramowym planem nauczania.
} 
rodzi się pytanie: po co znajomość procedury rejestracji firmy czy pisania planu biznesowego? Przyjmując takie założenie, można by zrezygnować z punktu dotyczącego samozatrudnienia, a zaoszczędzone godziny przeznaczyć na inne ważne treści, np. poszukiwanie pracy. Pozostawienie zapisów w dotychczasowym kształcie wydaje się więc bezcelowe.

$\mathrm{Na}$ zakończenie warto jeszcze raz podkreślić, że zaproponowany projekt podstawy programowej jest znacznie lepszy od obowiązującej podstawy. Wydaje się, że uwzględnienie przedstawionych wyżej sugestii może wpłynąć na jej udoskonalenie.

\section{Comments about Project to the Changes in Curriculum of the Bases for Entrepreneurships (Prepared by the Institute of Public Affairs; Ordered by the Ministry of National Education)}

This article presents the analysis of the third version of the project on new curriculum for the bases of entrepreneurship in the school curriculum prepared by the Institute of Public Affairs. The goal of the study is to suggest changes, which could influence the further development of presented project. The comments refer to a general thesis, the transformation of presumptions and the goals of an education. They submit alterations to the contents and requirements of the school curriculum. The team of the Department of Entrepreneurship and Spatial Economy from Institute of Geography in the Pedagogical University in Cracow prepared analysis of the project. 